\title{
Developments in Improving Biodiesel Production from Animal Fats
}

\author{
Created by: Fidel Toldrá ${ }^{1},\left(\right.$ Leticia Mora $^{2}$, Fidel Toldra Reig $^{3}$ \\ 1, Instituto de Agroquimica y Tecnologia de los Alimentos (CSIC); \\ ftoldra@iata.csic.es \\ 2, CSIC, Instituto de Agroquímica y Tecnología de Alimentos, Avenida Agustin \\ Escardino 7, Paterna 46980, Valencia, Spain; lemoso@iata.csic.es \\ 3, Instituto de Tecnología Química (CSIC-UPV), Universitat Politècnica de València; \\ reigtold@gmail.com
}

Version received: 11 June 2020

check for updates

Animal fats, usually found as waste from slaughterhouses, meat processing industry, and cooking facilities, constitute some of the most relevant waste with costly treatment because environmental regulations are quite strict. Part of such costs may be reduced through the generation of biodiesel that constitutes a valid renewable source of energy because it is biodegradable, non-toxic and has a good combustion emission profile. Furthermore, biodiesel can be blended up to $20 \%$ with fossil diesel for its use in many countries. Up to $70 \%$ of the total cost of biodiesel majorly depends on the cost of the raw materials used, which can be reduced using animal fat waste because they are cheaper than vegetable oil waste. Transesterification with alkaline catalysis is still preferred at industrial plants producing biodiesel. However, recent developments in technologies for process intensification like ultrasound, microwave, and different types of reactors have been successfully applied in transesterification and improved biodiesel production. Better efficiency has been achieved with new heterogeneous catalysts and nanocatalysts that can be easily recovered, regenerated and reused, and immobilized lipases with increased stability and resistance to alcohol denaturation. Also new adsorbents for increased oxidation stability of biodiesel. All these developments are promising for industrial use in near future.

\section{Introduction}

The production of biodiesel from animal fat waste requires a pretreatment that is necessary because feedstocks like animal fats usually contain large amounts of free fatty acids and water that reduce the yield of biodiesel ${ }^{[1]}$ and increase production costs because of the difficulty of separation and purification $[2][3]$. Then, biodiesel is produced through the transesterification reaction of fat with a short-chain alcohol, usually methanol, in the presence of a catalyst that can be alkaline, acid, heterogeneous catalysts like lipases or complex catalysts like silicates, zirconias and nanocatalysts. Refining and purification are the latest steps for removal of glycerol as well as other impurities like residual catalyst, unconverted fats, and soap. The European Union is the world's largest biodiesel producer and, on an energy basis, represents nearly $75 \%$ of the total transport biofuels market. In fact, the European biodiesel industry has more than 202 plants and production in 2019 exceeded 14 million tons of biodiesel [4][]. . US production of biodiesel was more than 5.6 million tons in 2019 and came from 91 plants with a capacity of 8.3 million tons per year [] $][\underline{7}]$. From total feedstock used for biodiesel production in 2019, $6 \%$ corresponded to animal fats. The latest advances for improving biodiesel production from animal fats are presented.

\section{Developments}

China has been the most active country in publishing patents in the period 1999-2018 with 647 patents on biodiesel. The US had 266 patents, with more than 50\% of them focused on reactors technology and processing methods ${ }^{[8]}$. There has also been patenting activity on pretreatment methods as well as on catalysts for improving the transesterification process. Specific examples of patents for biodiesel 
production from animal fat waste are shown in Table 1.

Table 1. Selected patents for biodiesel production from animal fat waste.

\begin{tabular}{|c|c|c|c|c|}
\hline $\begin{array}{l}\text { Animal } \\
\text { Feedstock }\end{array}$ & Particular Conditions & Catalyst & Biodiesel Characteristics & References \\
\hline $\begin{array}{l}\text { Lard oil, } \\
\text { tallow oil, fish } \\
\text { oil, }\end{array}$ & $\begin{array}{l}\text { Hydrodeoxygenation and } \\
\text { hydroisomerization of the } \\
\text { oil in a single step }\end{array}$ & $\begin{array}{l}\text { Pt and Pd } \\
\text { and an } \\
\text { acidic } \\
\text { component }\end{array}$ & $\begin{array}{l}\text { Mixture of } \mathrm{C} 14 \text { to } \mathrm{C} 18 \text { paraffins having a } \\
\text { ratio of iso to normal paraffins of } 2 \text { to } 8 \text {; } \\
\text { less than } 5 \text { ppm sulfur; and acceptable } \\
\text { lubricity }\end{array}$ & {$[\underline{9}][\underline{10}][\underline{11}]$} \\
\hline $\begin{array}{l}\text { Animal oil, } \\
\text { fish oil, lard, } \\
\text { rendered } \\
\text { fats, tallow }\end{array}$ & $\begin{array}{l}\text { Unwanted water } \\
\text { removed by cross-flow } \\
\text { filtration }\end{array}$ & $\begin{array}{l}\text { Immobilized } \\
\text { lipase }\end{array}$ & $\begin{array}{l}\text { Separation of formed crude biodiesel and } \\
\text { crude glycerol from the second reaction } \\
\text { medium by using a fourth cross-flow } \\
\text { filtration cassette }\end{array}$ & {$[\underline{12}]$} \\
\hline Animal fats & $\begin{array}{l}\text { Degumming; physical } \\
\text { refining (heating and } \\
\text { vacuum pulling); and } \\
\text { glycerolysis }\end{array}$ & $\mathrm{H}_{2} \mathrm{SO}_{4}, \mathrm{ZnO}$ & $\begin{array}{l}\text { Possibility of using various starting } \\
\text { feedstocks with heat integration to } \\
\text { minimise operating costs }\end{array}$ & {$[\underline{13}]$} \\
\hline $\begin{array}{l}\text { Animal fats } \\
\text { incl. } 10-20 \% \\
\text { free fatty } \\
\text { acids }\end{array}$ & Esterification in two steps & $96 \% \mathrm{H}_{2} \mathrm{SO}_{4}$ & $\begin{array}{l}\text { The amount of } \mathrm{FFA} \text { in the mixture is } \\
\text { reduced to }<3 \% \text { by weight }\end{array}$ & {$[\underline{14}][\underline{15}]$} \\
\hline Animal fats & $\begin{array}{l}\text { Esterification reaction of } \\
\text { free fatty acids if higher } \\
\text { than a set value }\end{array}$ & $\begin{array}{l}\text { Alkali } \\
\text { catalyst } \\
\mathrm{KOH}\end{array}$ & $\begin{array}{l}\text { Distillation to remove byproducts like } \\
\text { glycerol and alcohol }\end{array}$ & {$[\underline{16}]$} \\
\hline $\begin{array}{l}\text { Beef oil, pork } \\
\text { oil, animal } \\
\text { fats such as } \\
\text { fish oil }\end{array}$ & $\begin{array}{l}\text { Transesterification with } \\
\text { lower alcohol content }\end{array}$ & $\begin{array}{l}\text { Alkali } \\
\text { catalyst } \\
\mathrm{KOH}\end{array}$ & $\begin{array}{l}\text { Reducing costs by producing glycerin } \\
\text { and glycerin derivatives in high yield and } \\
\text { purity }\end{array}$ & {$[\underline{17}]$} \\
\hline
\end{tabular}

\section{Technology}

Transesterification with alkaline catalysis is still preferred at industrial plants producing biodiesel but innovative technologies for process intensification, like ultrasound and microwave, have been developed to be applied in transesterification and improve biodiesel production. The goal is to improve the miscibility of oils and methanol and thus increase the yield of the transesterification [18][19]. Immiscible liquids can be emulsified at an industrial scale through the use of low frequency ultrasonic irradiation. In the case of microwave irradiation, reactants can be efficiently and rapidly heated to the target temperature [20]. Other process intensification technologies like static mixers [21], capillary reactors [22], microreactors [23][24], or oscillatory flow reactors $[\underline{25]}$ are also intended to accelerate the reaction rate and enhance biodiesel production. The use of microwave heating for animal fats containing up to $20 \%$ free fatty acids allowed for a decrease in the required time for free fatty acid reduction and increased the final yield $[\underline{26]}$. Another alternative was the use of supercritical methanol with temperatures of 300$400{ }^{\circ} \mathrm{C}$, pressures up to $41.1 \mathrm{MPa}$, alcohol to fat ratios of 3:1 and 6:1, and short time (between 2-6 min) that gave $88 \%$ conversion for chicken fat [27]. The yield of biodiesel obtained with refined lard could also be obtained with waste lard containing fatty acids and water with no need for pretreatment [2]. Supercritical processes give faster reaction rates with no catalyst and avoid the need for pretreatment even in the presence of free fatty acids and water associated with the use of animal fats [29]. Neste renewable diesel is produced through the hydrogen catalyzed conversion of triglycerides into the corresponding alkanes and propane. Nearly 3 million tons are produced in five plants and mixed with fossil diesel for its use in aviation, turbines, generators and ships [으]. 


\section{Catalysts}

New heterogeneous catalysts that can be easily recovered, regenerated and reused have been developed for biodiesel production. Such catalysts include alkaline earth metal oxides such as $\mathrm{CaO}$ and $\mathrm{MgO}$, hydrotalcite, acid zirconia and alumina-based catalysts and immobilized lipase []ㅡ. The use of a new nano catalyst consisting of $\mathrm{CaO} / \mathrm{CuFe}_{2} \mathrm{O}_{4}$ during the transesterification process was successfully assayed for biodiesel production from chicken fat ${ }^{[31]}$. A sodium silicate catalyst that does not saponify with free fatty acids during transesterification was recently assayed to produce biodiesel that could be blended up to $30 \%$ with diesel, giving good performance. The brake specific fuel was $26 \%$ higher than diesel and the brake thermal efficiency was $4 \%$ lower while CO was reduced by $24.4 \%$ and hydrocarbons by $22.9 \%$. However, no emission was increased by $11 \%$ at full load [32]. Shells of Mytilus galloprovincialis-waste from fish industry-containing $\mathrm{CaO}$ that can be used as a catalyst, were used for transesterification of jojoba oil. As $\mathrm{CaO}$ could be contaminated with $\mathrm{CO}_{2}$ and $\mathrm{H}_{2} \mathrm{O}$, it was calcined immediately before use ${ }^{[33}$. Calcined scallop shell was also reported as a very active catalyst for transesterification of rapeseed oil ${ }^{[34]}$. Recently, a cheap and safe catalyst consisting of metal hydrated salts was proposed for the pretreatment of animal fats with a high content of free fatty acids that could be esterified up to $99 \%$ with alcohol under mild conditions [풀. The methyl esters remained in the oily phase and could be used for transesterification directly with alkaline catalysts. On the other hand, a biorefining strategy for animal fat waste was proposed for the conversion of free fatty acids into triglycerides that could be blended with fossil diesel and be used in engine combustion systems [36].

A variety of lipases from diverse microorganisms such as Candida antarctica, Candida rugosa, Pseudomonas cepacia, Pseudomonas spp. and Rhizomucor miehei, and immobilized lipases, have been reported as effective for biodiesel production [9]. The use of lipases requires lower energy consumption and absence of soaps; another advantage is that lipases are specific and selective reducing the possibility of undesired reactions [37]. However, the costs of the enzyme are high, the enzyme can be denatured by alcohol and can be used only once. Immobilisation of the enzyme increases its stability and allows its reuse although some denaturation by alcohol may still exist [ ${ }^{38}$ ]. Transesterification with immobilised lipase in supercritical $\mathrm{CO}_{2}$ reduced the interaction between methanol and enzyme, and its toxicity with an immediate separation of $\mathrm{CO}_{2}$ from the product [39] Other authors have assayed the coimmobilisation of lipases on the same surface ${ }^{[40]}$ or layer by layer ${ }^{[\underline{41}]}$ in order to get better global activity.

\section{Adsorbents}

Recently, adsorbents like magnesium aluminum hydroxycarbonate and 1,3,5-trimethyl-2,4,6-tris(3,5ditert-butyl-4-hydroxybenzyl) benzene were proposed to enhance the oxidative stability of biodiesel and its blends and therefore retard their degradation. The acid value could be reduced up to $9 \%$. In this way, the adsorbents can remove the precursors of the aging of biodiesel by stabilizing the generated free radicals and preventing them from starting new oxidation chains ${ }^{[42]}$. Precipitates of steryl glucosides are found in biodiesel produced from vegetable oils and may produce filter blockage. Their removal is achieved through adsorption with $3 \%$ silica at $112{ }^{\circ} \mathrm{C}$ for $72 \min [\underline{43}]$.

\section{References}

1. T.M.I. Mahlia; Z.A.H.S. Syazmi; M. Mofijur; A.E. Pg Abas; M.R. Bilad; Hwai Chyuan Ong; A.S. Silitonga; Patent landscape review on biodiesel production: Technology updates. Renewable and Sustainable Energy Reviews 2020 , 118, 109526, 10.1016/j.rser.2019.109526.

2. US Energy Information Administration. Monthly Biodiesel Production Report. US Department of Energy: Washington, DC, USA. Retrieved 2020-6-8

3. Biodiesel basics . National Biodiesel Board, Washington, DC, USA. Retrieved 2020-6-8 
4. S.N. Gebremariam; Jorge Mario Marchetti; Economics of biodiesel production: Review. Energy Conversion and Management 2018, 168, 74-84, 10.1016/j.enconman.2018.05.002.

5. Tanawan Pinnarat; Phillip Savage; Assessment of Noncatalytic Biodiesel Synthesis Using Supercritical Reaction Conditions. Industrial \& Engineering Chemistry Research 2008, 47, 6801-6808, 10.1021/ie800542k.

6. Han Van Kasteren; A.P. Nisworo; A process model to estimate the cost of industrial scale biodiesel production from waste cooking oil by supercritical transesterification. Resources, Conservation and Recycling 2007, 50, 442-458, 10.1016/j.resconrec.2006.07.005.

7. Marta Ramos; Dias; Puna; João F. Gomes; João Bordado; Ana Paula Soares Dias; Jaime Puna; Biodiesel Production Processes and Sustainable Raw Materials. Energies 2019, 12, 4408, 10.3390/en12234408.

8. Dieter Bockey; The significance and perspective of biodiesel production - A European and global view. OCL 2019, 26, 40, 10.1051/ocl/2019042.

9. Z. Helwani; M.R. Othman; N. Aziz; Jinsoo Kim; W.J.N. Fernando; Solid heterogeneous catalysts for transesterification of triglycerides with methanol: A review. Applied Catalysis A: General 2009, 363, 1-10, 10.1016/j.apcata.2009.05.021.

10. Herskowirz, M.; Landau, M.; Reizner, I.; Kaliya, M. Production of Diesel Fuel from Vegetable and Animal Oils. U.S. Patent Application US2006207166, 28 September 2006

11. Herskowitz, M. Reaction System for Production of Diesel Fuel from Vegetable and Animal Oils. World Patent WO2008035155, 20 March 2008.

12. Hoff, M.V.; Benson, T.; Bell, J.; Pugh, M. Biodiesel Fuel Production, Separation Methods and Systems. U.S. Patent 13765782, 16 February 2012.

13. Lavella, P.S.R.; Pullo, P.; Pullo, G.V. Method and System for Integrated Biodiesel Production. U.S. Patent US20140020282A1, 23 January 2014.

14. Scott, M. Process for Producing Biodiesel and Related Products. World Patent WO2014202980A3, 19 June 2014.

15. Scott, M. Process for Producing Biodiesel and Related Products. China Patent CN106753812A, 31 May 2017.

16. Matsumura, M. Method for Producing Biodiesel Fuel. Japanese Patent JP2005350632A, 22 December 2015.

17. Matsumura, M. Technique for Producing Low-Exhaust Type Biodiesel Fuel. Japanese Patent JP2005350630A, 22 December 2015.

18. Hee-Yong Shin; Si-Hong Lee; Jae-Hun Ryu; Seong-Youl Bae; Biodiesel production from waste lard using supercritical methanol. The Journal of Supercritical Fluids 2011, 61, 134-138, 10.1016/j.supflu.2011.09.009.

19. Carmen Stavarache; Mircea Vinatoru; Y. Maeda; Aspects of ultrasonically assisted transesterification of various vegetable oils with methanol. Ultrasonics Sonochemistry 2007, 14, 380-386, 10.1016/j.ultsonch.2006.08.004.

20. A. Breccia; B. Esposito; G. Breccia Fratadocchi; A. Fini; Reaction Between Methanol and Commercial Seed Oils Under Microwave Irradiation. Journal of Microwave Power and Electromagnetic Energy 1999, 34, 3-8, 10.1080/08327823.1999.11688383.

21. J. C. Thompson; B. B. He; Biodiesel Production Using Static Mixers. Transactions of the ASABE 2007, 50, 161-165, 10.13031/2013.22389.

22. Juan Sun; Jingxi Ju; Lei Ji; Lixiong Zhang; Nanping Xu; Synthesis of Biodiesel in Capillary Microreactors. Industrial \& Engineering Chemistry Research 2008, 47, 1398-1403, 10.1021/ie070295q.

23. Akansha Madhawan; Arzoo Arora; Jyoti Das; Arindam Kuila; Afroz Alam. Vinay Sharma; Microreactor technology for biodiesel production: a review. Biomass Conversion and Biorefinery 2017, 8, 485-496, 10.1007/s13399-017-0296-0.

24. José Martim Costa Junior; Carolina P. Naveira-Cotta; Diego Busson De Moraes; Paulo Inforçatti Neto; Izaque Alves Maia; Jorge Vicente Lopes Da Silva; Haimon Alves; Manish K. Tiwari; Cristiane Gimenes Souza; Innovative Metallic Microfluidic Device for Intensified Biodiesel Production. Industrial \& Engineering Chemistry Research 2019, 59, 389398, 10.1021/acs.iecr.9b04892.

25. Adam P. Harvey; Malcolm R Mackley; Thomas Seliger; Process intensification of biodiesel production using a continuous oscillatory flow reactor. Journal of Chemical Technology \& Biotechnology 2003, 78, 338-341, 10.1002/jctb.782.

26. Ertan Alptekin; Mustafa Canakci; Optimization of transesterification for methyl ester production from chicken fat. Fuel 2011, 90, 2630-2638, 10.1016/j.fuel.2011.03.042.

27. Victor F. Marulanda; George Anitescu; Lawrence L. Tavlarides; Investigations on supercritical transesterification of chicken fat for biodiesel production from low-cost lipid feedstocks. The Journal of Supercritical Fluids 2010, 54, 5360, 10.1016/j.supflu.2010.04.001.

28. Manhoe Kim; Craig DiMaggio; Shuli Yan; Huali Wang; Steven O. Salley; K Y Simon Ng; Performance of heterogeneous ZrO2 supported metaloxide catalysts for brown grease esterification and sulfur removal. Bioresource Technology 2011, 102, 2380-2386, 10.1016/j.biortech.2010.10.105.

29. Ivana Banković-Ilić; Ivan J. Stojković; Olivera S. Stamenković; Vlada B. Veljković; Yung-Tse Hung; Waste animal fats as feedstocks for biodiesel production. Renewable and Sustainable Energy Reviews 2014, 32, 238-254, 
10.1016/j.rser.2014.01.038.

30. Neste Renewable Diesel Handbook. Neste. Retrieved 2020-6-10

31. Kambiz Seffati; Bizhan Honarvar; Hossein Esmaeili; Nadia Esfandiari; Enhanced biodiesel production from chicken fat using $\mathrm{CaO} / \mathrm{CuFe2O} 4$ nanocatalyst and its combination with diesel to improve fuel properties. Fuel 2019, 235, 12381244, 10.1016/j.fuel.2018.08.118.

32. Jinlin Xue; Tony E. Grift; Alan C. Hansen; Effect of biodiesel on engine performances and emissions. Renewable and Sustainable Energy Reviews 2011, 15, 1098-1116, 10.1016/j.rser.2010.11.016.

33. Marcos Sánchez; Jorge Mario Marchetti; Noureddin El Boulifi; Jose Aracil; María-Aránzazu Martínez; Kinetics of Jojoba oil methanolysis using a waste from fish industry as catalyst. Chemical Engineering Journal 2015, 262, 640-647, 10.1016/j.cej.2014.09.088.

34. Masato Kouzu; Akio Kajita; Akitoshi Fujimori; Catalytic activity of calcined scallop shell for rapeseed oil transesterification to produce biodiesel. Fuel 2016, 182, 220-226, 10.1016/j.fuel.2016.05.111.

35. Luigi Di Bitonto; Carlo Pastore; Metal hydrated-salts as efficient and reusable catalysts for pre-treating waste cooking oils and animal fats for an effective production of biodiesel. Renewable Energy 2019, 143, 1193-1200, 10.1016/j.renene.2019.05.100.

36. Mbalo Ndiaye; Abdellah Arhaliass; Jack Legrand; Guillaume Roelens; Anthony Kerihuel; Reuse of waste animal fat in biodiesel: Biorefining heavily-degraded contaminant-rich waste animal fat and formulation as diesel fuel additive. Renewable Energy 2020, 145, 1073-1079, 10.1016/j.renene.2019.06.030.

37. João H. C. Wancura; Marcus V. Tres; Sérgio L. Jahn; J. Vladimir Oliveira; Lipases in liquid formulation for biodiesel production: Current status and challenges. Biotechnology and Applied Biochemistry 2019, -, 1-20, $10.1002 /$ bab.1835.

38. Baskar Thangaraj; Pravin Raj Solomon; Bagavathi Muniyandi; Srinivasan Ranganathan; Lin Lin; Catalysis in biodiesel production-a review. Clean Energy 2018, 3, 2-23, 10.1093/ce/zky020.

39. Patricia C.M. Da Rós; Guilherme A.M. Silva; Adriano Assis Mendes; Júlio C. Santos; Heizir F. De Castro; Evaluation of the catalytic properties of Burkholderia cepacia lipase immobilized on non-commercial matrices to be used in biodiesel synthesis from different feedstocks. Bioresource Technology 2010, 101, 5508-5516, 10.1016/j.biortech.2010.02.061.

40. Mohadese Babaki; Maryam Yousefi; Zohreh Habibi; Mehdi Mohammadi; Process optimization for biodiesel production from waste cooking oil using multi-enzyme systems through response surface methodology. Renewable Energy 2017, 105, 465-472, 10.1016/j.renene.2016.12.086.

41. Sara Arana-Peña; Nathalia S. Rios; Carmen Mendez-Sanchez; Yuliya Lokha; Diego Carballares; Luciana R. B. Gonçalves; Roberto Fernández-Lafuente; Coimmobilization of different lipases: Simple layer by layer enzyme spatial ordering. International Journal of Biological Macromolecules 2020, 145, 856-864, 10.1016/j.ijbiomac.2019.10.087.

42. Jerome Kpan; Jürgen Krahl; Sustaining the Oxidation Stability of Biodiesel and Its Blends in Plug-in Hybrid Vehicles Using Adsorbents. Energy \& Fuels 2019, 33, 11181-11186, 10.1021/acs.energyfuels.9b02828.

43. Potjanee Saeong; Maythee Saisriyoot; Anusith Thanapimmetha; Penjit Srinophakun; The response surface optimization of steryl glucosides removal in palm biodiesel using silica adsorption. Fuel 2017, 191, 1-9, 10.1016/j.fuel.2016.11.023.

\section{Keywords}

biodiesel; fuel; energy generation; agricultural waste; food waste; animal waste; lard; tallow; animal fat; transesterification 